\title{
スクリューフィーダーの供給特性に及ぼす粉体のかさ密度 および流動性の影響
}

\author{
Effect of Bulk Density and Flowability of Powders on the Feed \\ Rate of Screw Feeder
}

\author{
木俣 光正 ${ }^{\mathrm{a} *}$, 辻川 浩雄 ${ }^{\mathrm{a}}$, 松本 幹治 $^{\mathrm{b}}$ \\ Mitsumasa Kimata, Hiroo Tsujikawa, Kanji Matsumoto
}

\begin{abstract}
The effect of mechanical properties and rotating speed of screw on the feed rate was studied using aluminum hydroxide powder and calcium carbonate powder treated with stearic acid. In general, linear relationship was obtained between the feed rate and the rotating speed of screw although the linearity is somewhat weak for two types of untreated powder and those treated with $0.2 \mathrm{wt} \%$ stearic acid. As the stearic acid concentration increased, the feed rate, that is, the slope of straight line $\alpha$, increased. The aerated and packed bulk densities increased with the stearic acid concentration, implying that the flowability of powder was improved as the concentration of stearic acid became higher. The value of $\alpha$ was well correlated with the bulk density of powder collected at the outlet of screw feeder and the flowability measured by the shear tests and tensile strenght tests.
\end{abstract}

Key Words : Screw feeder, Flowability, Stearic acid, Aluminium hydroxide powder, Calcium carbonate powder

\section{1. 緒言}

粉粒体の供給特性は装置の種類，粉体の特性（粉体 の種類, 粒度分布, 密度, 流動性など）の影響を受け る。特にホッパー内の付着やフィーダーへの付着は, 供給量を変動させ供給操作のトラブルの原因となる。 したがって, 円滑な供給を行うには供給する粉体の物 性に適合する供給装置の選定が必要になる。スクリ ューフィーダーは粉粒体の連続供給機として広く使用 されており，粒子排出量に関する操作条件，実験式が

\section{0 年 9 月 1 日受付}

$\mathrm{a}$ 粉体工学会夏期シンポジゥム（2000年 7 月, 神奈川県葉山）にて 発表

\section{神奈川工科大学応用化学科}

（テ243-0292 厚木市下荻野1030）TEL 046-291-3216

Department of Applied Chemistry, Kanagawa Institute of Technology

(1030 Shimo-ogino, Atsugi-shi, 243-0292)

$\mathrm{b}$ 横浜国立大学工学部物質工学科

（テ240-8501 横浜市保土ケ谷区常盤台79-5）TEL 045-339-4008 Department of Material Science and Chemical Engineering, Yokohama National University

(79- 5 Tokiwadai, Hodogaya-ku, Yokohama-shi, 240-8501)

* 現 山形大学工学部物質化学工学科

（テ992-8510 米沢市城南 4-3-16） TEL 0238-26-3157

Department of Chemistry and Chemical Engineering,

Yamagata University

(4-3-16 Jonan, Yonezawa-shi, Yamagata 992-8510)
報告されている1”。しかし，供給特性を表す式中に含 まれる粉体物性は, フィーダー内のかさ密度のみであ り, 粉粒体の力学的特性と供給特性の関係に関する研 究は少ない2,3)。

そこで本研究では, 流動特性の異なるステアリン酸 処理粉体を用い，スクリューフィーダーにおける粉体 の供給速度, 供給精度と粉体の力学的特性の関係につ いて検討した。滑沢剂あるいは疎水化剂として使用さ れているステアリン酸による粉体表面処理は，粒径分 布にほとんど影響を与えずに流動特性を変化させるこ とが可能であり ${ }^{4)}$, 粒子径の影響を小さくすることが できる。なお，粉体の流動性は夕ッピング試験およ び平行平板型剪断試験 ${ }^{5.6)}$, 水平 2 分割セル型引張破 断試験》により得られる流動度 FIにより評価し，フ ィーダー内の粉体物性はスクリューフィーダーから排 出された粉体のかさ密度により評価した。

\section{2. 実験}

\section{1 試料粉体}

本実験に用いた試料粉体は, 水酸化アルミニウム B-103, 炭酸カルシウム $\mathrm{P}-30$ および B-103， P-30 をステアリン酸で表面処理した粉体（日本軽金属(侏) 提供）である。試料粉体の表面処理は以下の方法で行 


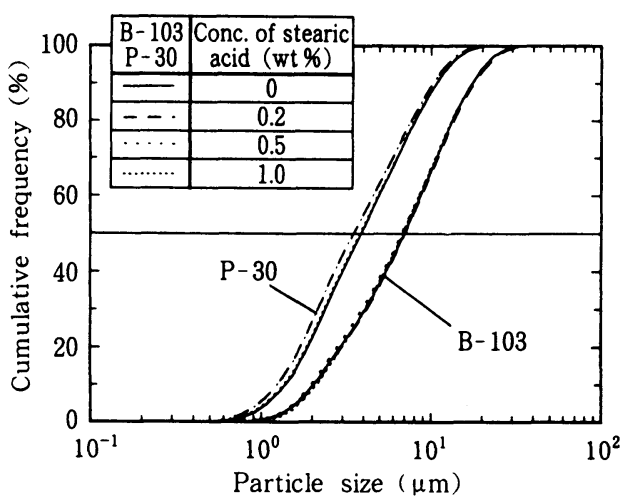

Fig. 1 Cumulative particle size distribution of sample powder

った。 $2 \mathrm{~kg}$ の末処理水酸化アルミニウム粉体または 炭酸カルシウム粉体と $0.1 \sim 1.0 \mathrm{wt} \%$ のステアリン酸 を同時に内容積約 $10^{-2} \mathrm{~m}^{3}$ のヘンシェルミキサーに入 れ, 約 $353 \mathrm{~K}$ に加温しながら擋找羽根で約 $15 \mathrm{~m} / \mathrm{s}$ の 先端速度で 10 分間混合した。Fig. 1 に，レーザー回折 式粒度分布測定装置（㑣セイシン企業 LMS-30）に より測定した試料粉体の粒子径分布を示した。なお， 試料粉体はへキサメタリン酸ナトリウム $0.1 \mathrm{wt} \%$ 水 溶液に分散後，この懸濁液を測定適正濃度になるまで 希釈して粒子径分布を測定した（㑣セイシン企業に
測定依頼)。Fig. 1より，ステアリン酸処理しても水 酸化アルミニウム $\mathrm{B}-103$, 炭酸カルシウム $\mathrm{P}-30$ の メディアン径はそれぞれ約 $6.9 \mu \mathrm{m} ， 3.6 \mu \mathrm{m}$ であり， 粒子径分布にほとんど影響を及ぼさないことが確認で きた。これらの粉体はそれぞれ大気中 $338 \mathrm{~K} ， 12$ 時 間以上加熱乾燥し, その後, 密閉性の良い容器に入れ 充分冷却したものを測定試料として用い，一度使用し た粉体は再度乾燥させて用いた。なお，粉体の真密度 は厳密にはステアリン酸処理により変化すると思われ るが, 処理濃度が最大 $1.0 \mathrm{wt} \%$ と少ないことからす へて B-103 およびP-30は机ぞれ $2.4 \times 10^{3}$ および $2.7 \times 10^{3} \mathrm{~kg} / \mathrm{m}^{3}$ とした。

\section{2 実験装置}

スクリューフィーダー（赤武エンジニアリング(株) 製）の概略を Fig. 2 に示す。フィーダー内径は 45 $\mathrm{mm}$ ，スクリューは外径 $35 \mathrm{~mm}$, シャフト直径は $18 \mathrm{~mm}$ であり，ピッチはホッパー側から粉体排出口 まで $32 \mathrm{~mm}$ から $28 \mathrm{~mm}$ と徐々に狭くなっている。な お，ホッパーには試料粉体の閉塞防止およびフィー ダー内に粉体を安定供給させるため，リボン型の擋拌 機を設置した。また，フィーダーから排出された粉体

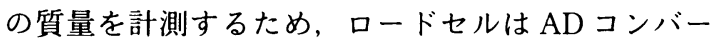
ターを介してパソコンと接続させた。

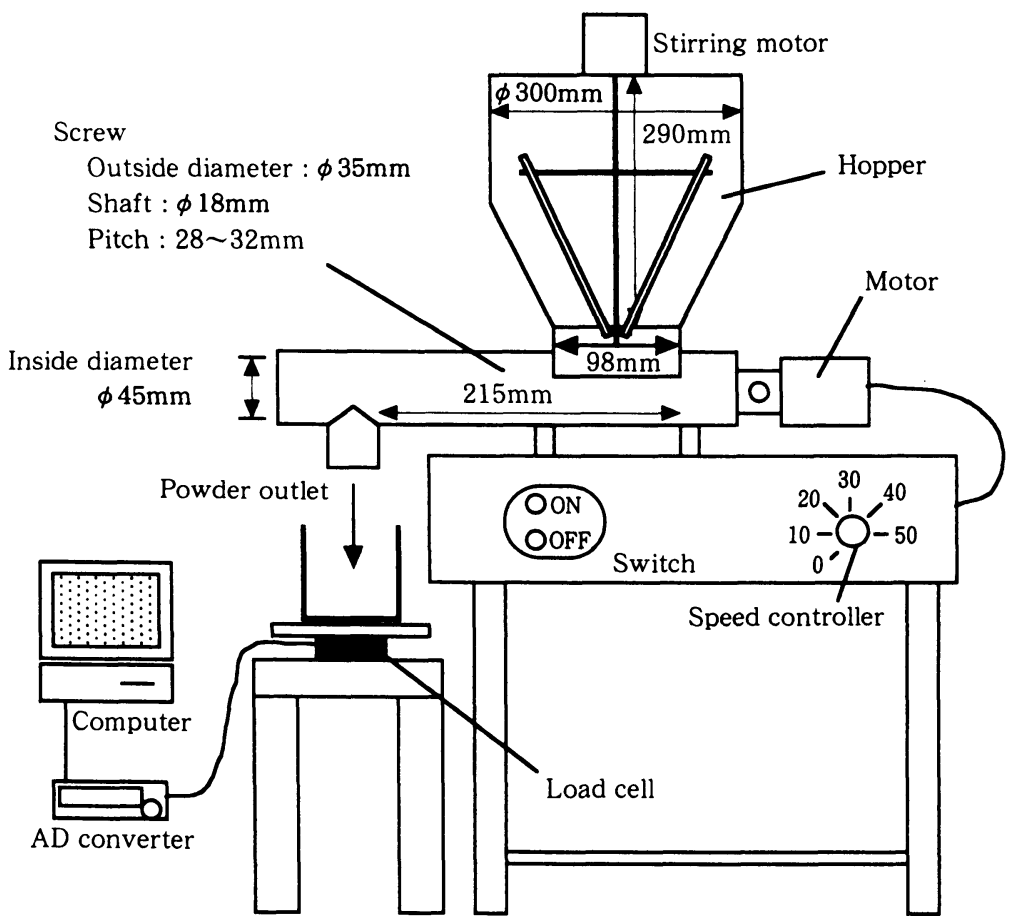

Fig. 2 Schematic diagram of screw feeder 
タッピング試験は, タッピング高さ $20 \mathrm{~mm}$ のパウ ダーテスタ（ホソカワミクロン(粕 PT-E) のタッピ ング装置を利用して行い, タッピング用セルは内径 $50 \mathrm{~mm}$, 高さ $100 \mathrm{~mm}$, 内容積 $190 \mathrm{~cm}^{3}$ のポリプロピ レン製容器を作製した。

引張破断試験および剪断試験は, パウダーベッドテ ス夕（三協パイオテク 俰 PTHN-13BA）により行っ た。引張破断用セルは可動部と固定部からなってお り, 直径 $50 \mathrm{~mm}$, 高さ $20 \mathrm{~mm}$ の円筒型で, 水平方向 に2 分割させる構造になっている。剪断試験はノッチ 付きの平行平板式であり, 上部可動板と粉体層の接触 面積は $35 \mathrm{~cm}^{2}$ である。

\section{3 実験方法}

2. 3. 1 スクリューフィーダーの粉体供給試験

スクリューフィーダー付属のホッパーに乾燥済みの 試料粉体を目開き $2.80 \mathrm{~mm}$, 直径 $150 \mathrm{~mm}$ のステン レス製標準ふるいを通して投入し，ホッパー内に設置 した摚拌機を $0.17 \sim 0.33 \mathrm{rps} に て$ 回転させた。フィー ダーのスクリュー回転数を $0.17 \sim 0.82 \mathrm{rps}$ に設定し,

スクリューの回転と同時にロードセルによる排出口か らの粉体質量の計測を開始した。ロードセルから得ら

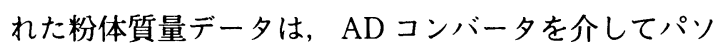
コン内に $1 \sim 5$ 秒間隔で保存した。

\section{3.2 粉体の力学的特性の測定}

タッピング試験は, 試料をシリンダの上方から目開 き $710 \mu \mathrm{m}$ のふるいを通して粗充媜し, 上面を水平に すりきり所定回数タッピングを行った。ゆるみ見かけ 密度を夕ッピング回数 $n=0$, かため見かけ密度は夕 ッピングを繰り返しても粉体層高さが変わらなくなっ た $n=1200$ の粉体の容積（粉体層高さ最大, 最小の 2 力所の平均值) から求めた。

引張破断および剪断試験は前報 ${ }^{8)}$ と同様の方法で行 った。得られた実験結果から, Warren-Spring 式に よる破壊包絡線を描き，これに接するモール円により 単軸崩壊応力 $f_{\mathrm{c}}$ を求めた。また, 受動破壊応力 $\sigma_{1}$ は 平行平板型剪断試験機を使用しているため, 粉体層に かけた圧密応力 $p$ の値を用いた ${ }^{6)}$ 。

\section{3.3 スクリューフィーダー内のかさ密度測定}

供給速度がフィーダー内粉体のかさ密度に与える影 響を調査するため, フィーダーから排出された粉体の かさ密度を測定した。測定には, 直径 $50 \mathrm{~mm}$, 高さ $50 \mathrm{~mm}$, 内容積 $100 \mathrm{~cm}^{3}$ のステンレス製容器を使用し た。スクリューを回転させた後, 重力の影響をあまり 受けないように容器をスクリューフィーダー粉体排出 口のすぐ下に設置し，左右に動かしながら排出された

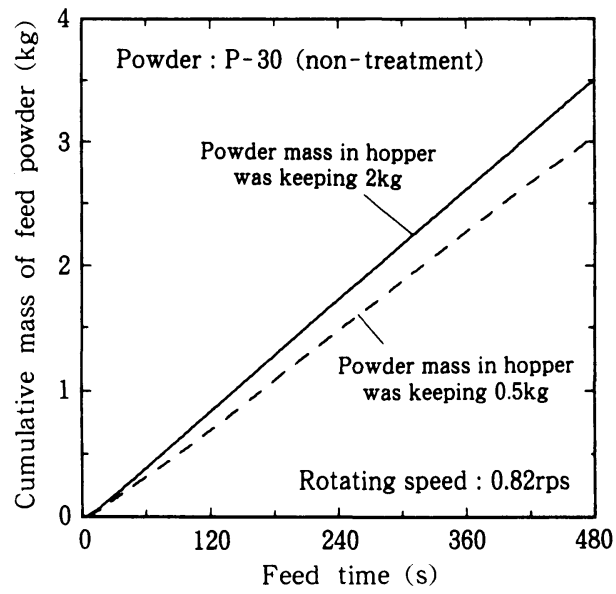

Fig. 3 Effect of powder mass in hopper on feed rate

粉体を容器に満たした。容器の上端を水平にすり切 り, 粉体質量を測定することによりかさ密度を算出し た。なお，この方法により測定されたかさ密度は, 必 ずしもフィーダー内における粉体の真のかさ密度と一 致しない可能性はあるが, 相対的な值を得る方法とし ては有効であると思われる。

\section{3. 結果および考察}

\section{1 スクリューフィーダーの供給特性}

\section{1.1 ホッパー内粉体量の影響}

スクリューフィーダーの供給速度は，ホッパー内の 粉体量により影響を受けると思われる。Fig. 3に，ス クリューが回転している間, ホッパー内の粉体量を, ホッパー上端から $100 \mathrm{~mm}$ (約 $2 \mathrm{~kg}$ ）または上端から $200 \mathrm{~mm}$ (約 $0.5 \mathrm{~kg}$ ) のところで一定となるように，ふ るいを通して粉体を連続的にホッパーに投入したとき に, ロードセルから得られる粉体の供給量の経時変化 を示した。使用した粉体は炭酸カルシウム P-30 未処 理のものであり, スクリュー回転数は $0.82 \mathrm{rps}$ とし た。図より，ホッパー内の粉体量の違いによりフィー ダーの供給量は異なり, ホッパー内の粉体量が多けれ ば供給速度も大きくなることがわかる。これは, ホッ パー内の粉体量が多いほど粉体がホッパー内で压密さ れたからであると思われる。このように，ホッパー内 の粉体量が供給速度に影響を及ぼすため, 以後の実験 はスクリューが回転している間, 粉体投入高さがホッ パー上端から $100 \mathrm{~mm}$ のところで一定になるようにホ ッパー上部から連続的に粉体を供給して行った。 


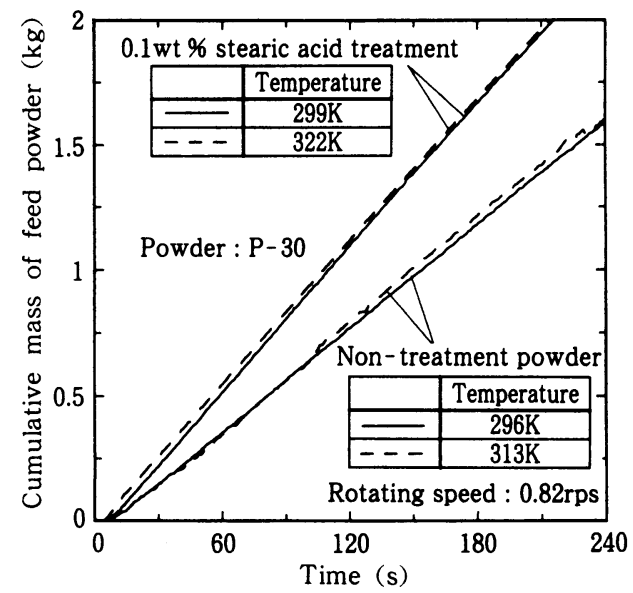

Fig. 4 Effect of powder temperature in feeder on feed rate

\section{1.2 粉体温度の影響}

使用する粉体は $338 \mathrm{~K}$ にて乾燥後, 室温まで冷却す る。粉体の温度が供給速度に及ぼす影響を調査した。 Fig. 4 に，乾燥した粉体をほとんど冷却せずに用いた ものと室温まで冷却したものの粉体供給量の経時変化 を示す。なお，使用した粉体は炭酸カルシウム $\mathrm{P}-30$ 未処理および $0.1 \mathrm{wt} \%$ ステアリン酸処理したもので おり，スクリュー回転数は 0.82rps とした。図中に示 した温度は, フィーダーから排出された粉体の温度の 平均値である。図より，ステアリン酸処理した粉体の 方が供給速度は大きくなっているが, 粉体温度の違い による供給量の違いは見られなかった。しかしなが ら，本実験では供給速度の測定は実験条件を一定にす るため，室温まで冷却した粉体を用いた。

\section{1.3 スクリュー回転数の影㫼}

Fig. 5に，水酸化アルミニウム粉体 B-103を用いた ときの, フィーダーの供給速度 $X$ とスクリュ一回転 数 $N$ の関係を示した。このとき，供給速度は 5 秒間 隔で得られた供給量の平均值により求めたものであ り, 図中のエラーバーは標準偏差を示している。図よ り，未処理粉体を除いて 0.75rps 以下の回転数におい て直線関係が得られ, 以下の式で整理することができ た。

$$
X=\alpha \cdot N
$$

ただし， $\alpha$ は実験定数である。また，ステアリン酸濃 度の增加とともに同じ回転数における供給速度は大き くなり， $\alpha$ の值も大きくなることがわかった。回転数 0.82rps を見るといずれも比較的標準偏差が大きく， 特にステアリン酸処理したものの供給速度は急激に変

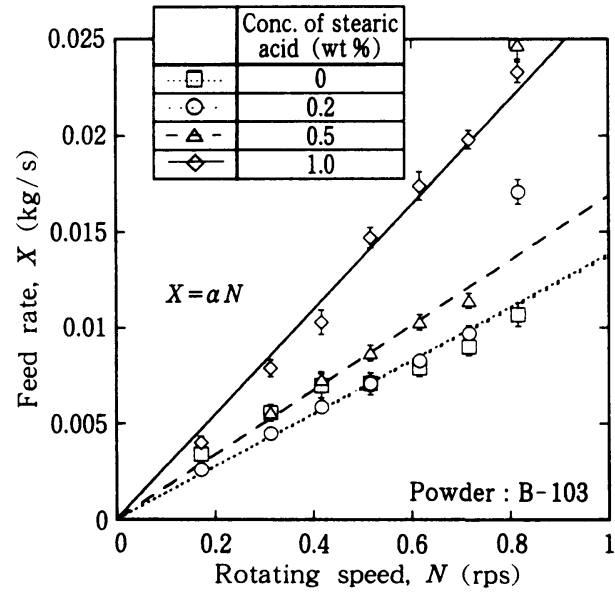

Fig. 5 Relationship between $X$ and $N$ (B-103 powder)

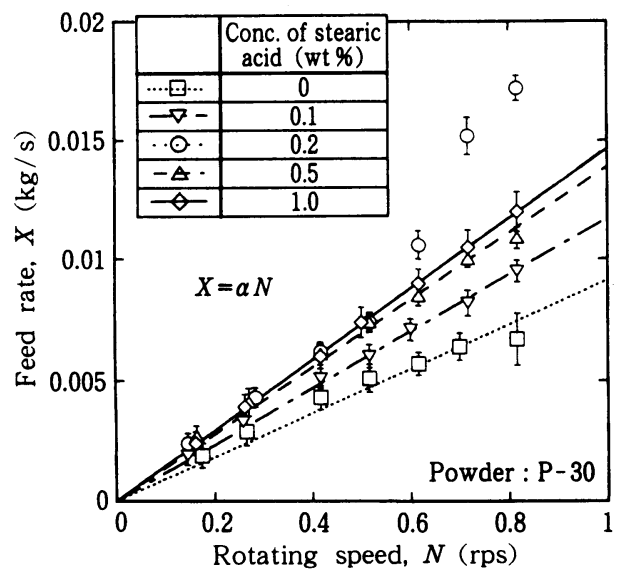

Fig. 6 Relationship between $X$ and $N$ (P-30 powder)

化している。また，未処理粉体の場合，0.42rps を境 として供給速度は低下している。いずれの場合も再現 性があるために，このような異常挙動が生じる原因と してフィーダーの構造, フィーダー内のかさ密度, 壁 面摩擦の変化などの影響が考えられるが詳細は不明で ある。

Fig. 6 に，炭酸カルシウム粉体 P-30を用いたとき の供給速度 $X$ と回転数 $N$ の関係を示した。Fig. 5 と 同様の方法により供給速度を求め，標準偏差をエラー バーで示した。図より，ステアリン酸濃度が高くなる と供給速度は大きくなることがわかる。また， $0.2 \mathrm{wt}$ \%ステアリン酸処理は 0.52rps 以下，末処理 $\mathrm{P}-30$ 粉体では 0.42rps 以下, その他は全ての回転域で直線 関係が得られており, 水酸化アルミニウム粉体 $\mathrm{B}$ 103 と同様に Eq. (1) により整理することができる。 


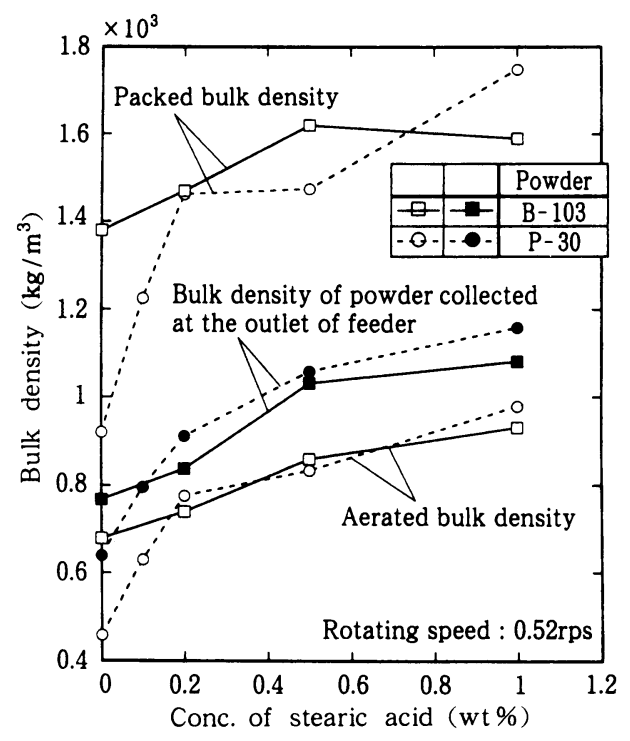

Fig. 7 Effect of stearic acid concentration on three kinds of bulk density

標準偏差は B-103 粉体に比べて大きくなっており， 粒子径など粉体物性の影響が現れているものと思われ る。未処理粉体と $0.2 \mathrm{wt} \%$ ステアリン酸処理 $\mathrm{P}-30$ 粉体は，ある回転数以上で低回転数時の直線関係から ずれ，かつ未処理粉体と $0.2 \mathrm{wt} \%$ ステアリン酸処理 粉体とのずれる傾向は異なるが，その原因は現状では 明らかではない。

\section{2 粉体の力学的特性に及ぼすステアリン酸濃度 の影響}

\section{2.1 かさ密度}

供給速度に影響を及ぼす因子のひとつであるフィー ダー内の粉体のかさ密度を測定するため, フィーダー から排出された粉体のかさ密度測定を行った。Fig. 7 に, 回転数 $0.52 \mathrm{rps}$ における B- 103 および $\mathrm{P}-30$ 粉 体の排出された粉体のかさ密度とステアリン酸濃度の 関係を示した。また, タッピング試験から得られた粉 体の力学的特性である, ゆるみ, かため見かけ密度も 合わせて示した。図より，ステアリン酸濃度が高くな るとともにかさ密度は大きくなっていることがわか る。また，ゆるみおよびかため見かけ密度をみると， ステアリン酸濃度によるフィーダー内のかさ密度の変 化と相関関係を示していることから，ステアリン酸濃 度が高いほど粉体の流動性がよく，ホッパーやフィー ダー内での空隙率が低くなっていることが考えられ る。

\section{2.2 流動 性}

引張破断試験および剪断試験から得られる粉体の力

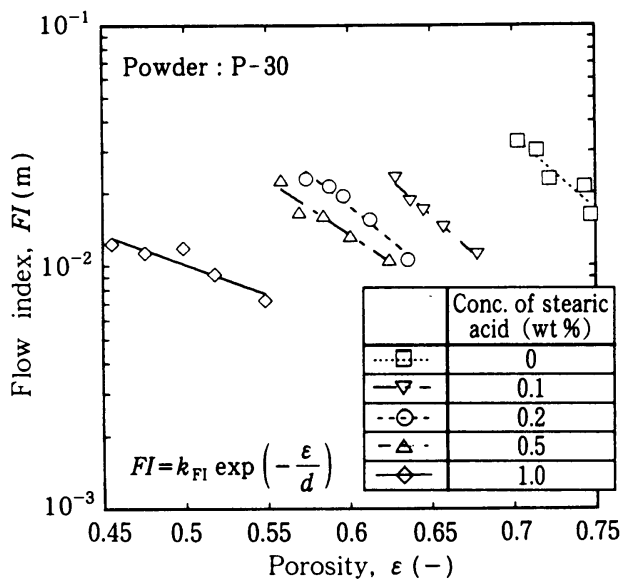

Fig. 8 Relationship between porosity of $\mathrm{P}-30$ powder bed and flow index

学的特性, 特に流動性に及ぼすステアリン酸濃度の影 響を次式で示される流動度 FIにより評価した。

$$
F I=\frac{f_{\mathrm{c}}}{\rho \cdot g}
$$

このとき, $f_{\mathrm{c}}$ は単軸崩壊応力, $\rho$ はかさ密度, $g$ は重 力加速度である。Fig. 8 に, 炭酸カルシウム粉体 P30 を用いたときの $F I$ と空隙率 $\varepsilon$ との関係を示す。図 より, 片対数上で直線関係が得られており, 我々が既 に報告した水酸化アルミニウム粉体 B-103 の場合と 同様に, FI について以下に示す実験式が成り立つこ とがわかる ${ }^{8)}$ 。

$$
F I=k_{\mathrm{Fl}} \exp (-\varepsilon / d)
$$

ただし， $k_{\mathrm{Fl}}, d$ は実験定数である。 $\mathrm{B}-103$ の場合 は, 直線の傾き，すなわち $-1 / d$ がステアリン酸濃 度によらずほぼ一定であったが, P-30 の場合は直線 の傾きがステアリン酸濃度の増加とともに小さくなっ ていることがわかる。このことから， P-30 もステア リン酸処理することにより B-103 と同様に流動性が 良くなることがわかった。

\section{3 供給特性之粉体の力学的特性の相関}

ここでは, 供給特性と粉体の力学的特性を比較し, その相関関係について検討した。Fig.9に，Eq. (1) により求めた比例定数 $\alpha$ と, フィーダーから排出され た粉体のかさ密度およびタッピング試験により求めた ゆるみ，かため見かけ密度との関係を示した。なお， $\alpha$ の值は変曲点が生じる粉体の場合は低回転時の直線 から求めたものである。図より， $\alpha$ とそれぞれ 3 種類 のかさ密度は両対数グラフ上で直線関係を示してお 


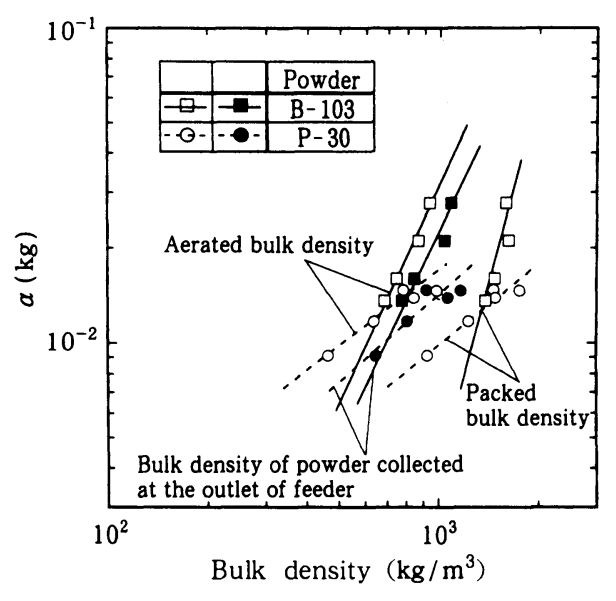

Fig. 9 Relationship between $\alpha$ and bulk density of powder

り，良好な相関が得られることがわかった。また，直 線の傾きは粉体の種類により異なっているが, 種類が 同じであればその傾きはほぼ一定である。フィーダー から排出された粉体のかさ密度は, いずれの粉体にお いてもゆるみおよびかため見かけ密度の間に位置して いることがわかる。

Fig. 10に，供給特性を示す $\alpha$ と粉体の流動性と関連 する $k_{\mathrm{FI}}$ との関係を示した。図より，いずれの試料粉 体においても $\alpha$ と $k_{\mathrm{FI}}$ は両対数グラフ上で直線関係を 示しており，良好な相関が認められることがわかっ た。 $F I$ は静止粉体層が崩壊するときの流動特性であ り，スクリューフィーダー内の粉体の状態とは異なる が，粉体の流動性が良いほど，供給速度は大きくなっ た。したがって, 力学的特性は供給特性に影響を及ば していると考えられる。また，Figs. 9，10における 直線の傾きは P-30 に比へて B-103 の方が大きいこ とから， B-103粉体の方が供給速度に対してかさ密 度および流動性の影響が大きいことがわかった。この ような差が生じた理由として, 粒子径, 付着力, フ イーダー壁面の摩擦力など様々な影響が考えられるが 詳細は不明である。さらに多くの種類の粉体について 検討する必要があると思われる。

\section{4. 結 言}

ステアリン酸処理することにより流動性を変化させ た炭酸カルシウム粉体 P-30 および水酸化アルミニウ

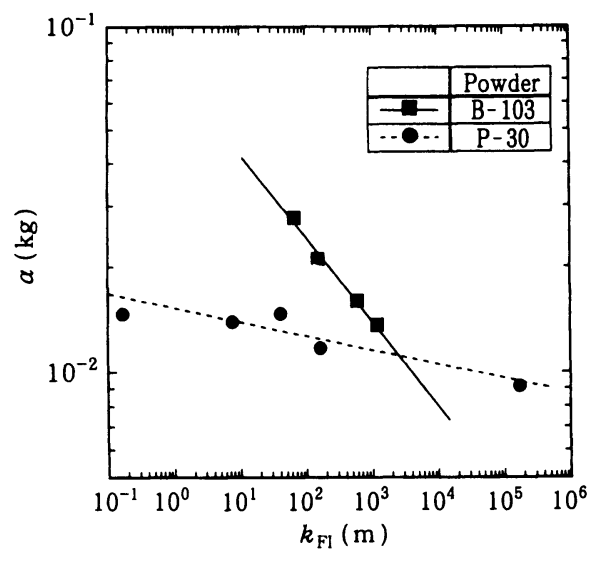

Fig. 10 Relationship between $\alpha$ and $k_{\mathrm{FI}}$

ム粉体 B-103 を用いて，スクリューフィーダーの供 給特性および粉体の力学的特性について比較検討し, 次のような結果を得た。

1 ) 試料粉体表面へのステアリン酸処理濃度が高いほ ど, 同じ回転数の供給速度は大きくなった。すなわ ち, 供給速度はスクリューの回転数にほほ比例し, Eq.（1）で表現できた。しかしながら，未処理粉体 および $0.2 w t \%$ ステアリン酸処理粉体においては, ある回転数以上で低回転数時の直線関係からずれる 傾向を示した。

2 ）ステアリン酸処理濃度が高いほど，ゆるみおよび かため見かけ密度, フィーダーから排出された粉体 のかさ密度が大きくなり, 流動性が向上した。

3）スクリューフィーダーの供給特性を示す実験定数 $\alpha$ は, フィーダーから排出された粉体のかさ密度, ゆるみ, かため見かけ密度および粉体の流動性に関 する実験定数 $k_{\mathrm{FI}}$ との間に良好な相関が得られた。

「謝辞」本研究を行うに当たり各種の試料粉体の提 供を受けた日本軽金属(侏)，粒子径を測定していただ いた株)セイシン企業，パウダーベッドテスタを借用 させて戴いた三協パイオテク (侏)，パウダーテスター を借用させて戴いたホソカワミクロン(侏)，スクリ ューフィーダーを借用させて戴いた赤武エンジニアリ ング侏，また，実験に協力していただいた神奈川工 科大学学生の塙幸久君, 平山孝雄君, 芳司健太郎君に 対し、ここに謝意を表します。

\section{Nomenclature}

$d$ : constant in Eq. (3)

FI : flow index
(-) $\quad f_{\mathrm{c}}$ : unconfined yield stress

(m) $g$ : gravitational acceleration
$(\mathrm{kPa})$ $\left(\mathrm{m} / \mathrm{s}^{2}\right)$ 
$k_{\mathrm{Fl}}$ : constant in Eq. (3)

$N$ : rotating speed

$n$ : number of tapping

$p$ : pre-consolidation stress

$X$ : feed rate

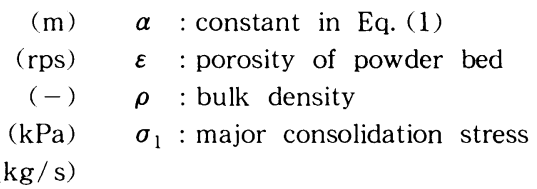

\section{References}

1) Aoki, R. et al. : "Hunryutai no Chozo to Kyokyusochi", p. 247, Nikkan Kogyo (1976),

Aoki, R. et al.: "Hunryutai no Bulk Handring Gijutsu”, p. 207, Nikkan Kogyo (1985),

Hayashi, T.: "Powder Technology Pocket Book", pp. 282-288, Kogyo Chosakai (1998)

2 ) Masuda, H., H. Kurahashi, M. Hirota and K. Iinoya : "Micro-Feeding by Table Feeder", Kagaku Kogaku Ronbunshu, 2, 286-290 (1976)

3 ) Matsumoto, K., G. Hong and K. Watanabe : "Effect of Powder Properties on the Feed Rate in Table Feeder", Proceeding of the Fourth Korea-Japan Powder Technology Seminar, 235-240 (1991)

4 ) Matsumoto, K., H. Akutsu, A. Yoshimidzu, G. Hong and K. Watanabe: "The Measurement of the Wettability of Hydrophobic Powder by the Constant Flow
Method", J. Soc. Powder Technol., Japan, 25, 359-364 (1988)

5 ) Hirota, M., T. Kobayashi and T. Oshima : "Proper Test Conditions for Measurement by a Direct Shear Tester with Parallel Plates", ibid., 20, 493-498 (1983)

6 ) Hirota, M., T. Kobayashi, O. Sano and T. Oshima : "Expansion and Contraction Behavior of a Powder Bed in a Shear Process", ibid., 21, 137-142 (1984)

7 ) Farley, R. and F. H. H. Valentin: "Problems Associated with Storage Hoppers", Trans. Inst. Chem. Eng., 43, 193198 (1965)

8 ) Kimata, M., H. Tsujikawa and K. Matsumoto: "Evaluation of Flow Properties of Aluminum Hydroxide Powder Treated with Stearic Acid”, J. Soc. Powder Technol., Japan, 36, 258-265 (1999) 